\title{
Critical Discourse Analysis and Educational Research
}

\author{
Nasir. H.S. Bukhari, Dr. Wang Xiaoyang \\ PhD Fellow (Higher Education) Institute of Education Tsinghua University, Beijing, China. \\ Director, Institute of Education Tsinghua University, Beijing,China
}

\begin{abstract}
In late 1970s a group of linguists and literary theorists at the University of East Angelia played a pivotal role in developing critical linguistics (Fowler et. al., 1979; Kress \& Hodges, 1979). CL was based on Halliday's Systematic Functional Linguistics (SFL). The Critical Linguists began to use CL as research tool (Fowler et. al., 1979; Fowler, 1991).CDA stemmed out from CL. Van Djik, Wodak, Leeuwen and Norman Fairclough are significant protagonists of CDA approach. Review of literature reveals that different models of CDA have come forth such as Van Djik (Socio-Cognitive Model), Wodak (Discourse Sociolinguistic), Leeuwen (Social Semiotics Model) and Fairclough(Critical Discourse Analysis). CDA is used to analyze the written and spoken texts to explore the discursive sources of power, dominance inequality and bias. It systematically explore the opaque relationships. The historical descriptive research methodology was used for this study. This paper aimed to review the literature related to CDA and its development and to find the answer of the question whether could we use CDA in educational research? The study revealed that CDA is an emerging approach and methodology that has successfully attracted the attention of researchers interested in carrying out research on the relationship between superstructures and social issues. The CDA is critiqued due to four reasons first, Political and Social ideologies are projected onto the data rather than being reveled through the data, second, there is an unequal balance between social theory and linguistic method, third any discourse analyses are extracted from social contexts and fourth, this methodology is not systematic (Roger, et al., 2003; Widdowson, 1998). Educational researchers are using this approach for instance, (Bloom \& Certer, 2001; Lemke, 1992; Peyntong-Young, 2001), studies of policy (Collins, 2001; Corson, 2000, Woodside-Jiron,2000), and interactions in classrooms and schools (Bloome \& Egan-Robertson, 1993; Kumarvadivelu, 1999; Roger,2003). CDA approach can be used in the field of educational research particularly to reveal the relationships between the ideology and power (a basic factor for national educational policy) as well as teaching and learning process.

Keywords: Critical Linguists (CL), Critical Discourse Analysis (CDA), Discursive Practices, Educational Policies, Semiotics.
\end{abstract}

\section{Introduction}

Critical Discourse Analysis (CDA) is a field that is used to analyze the written and spoken texts to explore the discursive sources of power, dominance inequality and bias. It critically evaluates how these discursive sources are maintained and reproduced within specific social, political, and historical contexts (Van Djik, 1998). CDA is a "discourse analysis which aims to systematically explore often opaque relationships of causality and determination between (a) discursive practices, events, and texts, and (b) wider social and cultural structures, relations and process; to investigate how such practices, events, and texts arise out of and are ideologically shape the relations of power and struggles over power; and to explore how the opacity of these relationships between discourse and society itself a factor securing power and hegemony" ( Fairclough, 1993). CDA simply aims to reveal the connections discourse practices that a layman can understand.

CDA stemmed out from Critical Linguistics (CL) in the late 1970s. A group of linguists and literary theorists at the University of East Angelia played a pivotal role in developing critical linguistics (Fowler et.al., 1979; Kress \& Hodges, 1979). CL was based on Halliday's Systematic Functional Linguistics (SFL). Trew, a CL practitioner, began "isolating ideology in discourse", and exhibiting "how ideology and ideological processes are manifested as system of linguistic characteristics and process". This aim led to develop CL's analytical tools based on FSL (Fowler et. al., 1979; Fowler, 1991).

CL practitioner following Halliday believed that language performs three functions; ideational, interpersonal, and textual. The ideational function refers to the experience of the speakers of the world and its phenomena, whereas the interpersonal function embodies the insertion speakers' own attitudes and evaluation about the phenomena in question, and establishing a relationship between speakers and listeners. Instrumental to these two functions is the textual function. The textual function of language enables the speakers for producing texts that are comprehended by listeners. Indeed, textual function enables connecting discourse to the co-text and con-text in which it happens (Fairclough, 1995b). 
Halliday's viewpoint of language as a 'social act' is the nucleus to many of CDA's practitioners (Chouliarki \& Fair Clough 1999, Fair Clough, 1989, 1992, 1993, 1995a; Fowler et al., 1979; Fowler 1991., Hodge \& Kress 1979). Sociolinguistics separates "the concepts" 'language' and 'society'... so that one is forced links between the two; whereas "language is an integral part of social process" (Fowler et al., 1979). Critical Discourse Analysis is a cross-disciplinary approach to the study of discourse, and is widely used for analyzing text and talk in organizational studies, humanities and social sciences.

There are two schools of thought for CDA, the traditional and Modern. The Traditional School sees the role of language as descriptive, but the Modern School of Social Constructionists suggests that discourses have the capability to (re-) construct social reality (Jorkinen et al. 1993, Fairclough, 2005). Indeed, to Fairclough (2005), the pioneer in the field of Critical Discourse Analysis in organizational studies, Social phenomena are socially constructed.

Since the beginning of the formalized education, research has been used to improve education and to determine in a wide range of situations. Through various research methods, teachers hope to obtain reliable and accurate information about important issue and problems that face the educational community. Knowledge of research is an essential as well as integral component of professional preparation for attaining skills and competence for all teachers. A must be knowledgeable about multifarious approaches of research to promote creative, innovative and sound solutions to learning and teaching issues (Bukhari et al. 2012). Since CDA is both a theory and a method. Researchers who are interested in the relationships between language and society use CDA to help them describe, interpret, and explain such relationships. Therefore, in the nut shell CDA is a attracting the attention of the social scientists as well as linguists to use as a research methodology.

\section{Definition}

\section{Review of Literature}

Critical Linguistics (CL) and Critical Discourse Analysis (CDA) can be best defined as " a shared perspective on doing linguistics, Semiotics, or discourse analysis" (VanDjik 1993b:131). CDA is based upon a view of Semiosis as an irreducible element of all material social processes (Williams, 1977). CDA is the practical linking of "social and political engagement with a sociologically informed construction of society" (Krings et al. 1978). According to Wodak (1989), CL and CDA may be defined as fundamentally interested in analyzing opaque as well as transparent structural relationships of dominance, discrimination, power and control as manifested in language. Thus, CDA aims to investigate critically social inequality as it is expressed, signaled, constituted, legitimized etc by language use (or in discourse).

Habermas,(1977) claims that "language is also a medium of domination and social force. It serves to legitimize the relations of organized power. In so far as the legitimization of power relations [...] are not articulated [...] language is also ideological". To Fairclough (1985), "in human matters, interconnections, and chains of cause and effects may be effected, distorted out of vision. Hence critique is essentially making visible the interconnectedness of things". For instance implicit argumentations and opaque texts are deconstructed and their underlying meanings are made explicit. The critical analysis performs the function of linking analyzed text to other connected discourses (intertextuality) and to historical and synchronic contexts.

Social life is interconnected relations of social practices of diverse sorts (economic. political, cultural, family etc). "The reason for centering the concept of 'social practice' is that it allows an oscillation between the perspective of social structure and the perspective of social action and agency -both necessary perspectives in social research and analysis (Chouliarki \& Fairclough, 1999). Thus, Fairclough,(1995) defines Critical Discourse Analysis (CDA) is an interdisciplinary approach to the study of discourse that views language as a form of social practice and focuses on the ways social and political domination are reproduced in text and talk. Social practice, according to Fairclough (1999), I mean a relatively stabilized form of social activity (examples would be classroom teaching, television news, family meals, medical consultation). Every practice is an articulation of diverse social elements within a relatively stable configuration, always including discourse.

These elements are dialectically related discourse (Harvey, 1996). CDA is not only analysis of dialectical relationships between discourses (including language) but also forms of Semiosis e.g. body language or visual images and other elements of social practices. CDA is an approach, research methodology and tool that aims at exploring the relationships between discourse practices, social practices and social structure, connections that could be opaque in nature.

The terms Critical Linguistics (CL) and Critical Discourse Analysis (CDA) are often used interchangeably. In fact, recently, the term CDA seems to have been preferred and is being used to denote the theory formerly identified as CL. Therefore, we will continue to use CDA exclusively here for an extensive discussion of these terms and their history). The manifold roots of CDA lie in Rhetoric, Text linguistics, Anthropology, Philosophy, Socio-Psychology, Cognitive Science, Literary Studies and Sociolinguistics, as well as in Applied Linguistics and Pragmatics. (Wodak, 2008). 
Critical Discourse Analysis (CDA) is a cross-disciplinary approach to the study of discourse, and is widely used for analyzing text and talk in organizational studies, humanities and social science (Vaara \& Tienari 2004).

\section{Evolution of CDA}

The origin of CDA can be traced in critical theory of language which considers the use of language as a form of social practice. All social practices possess specific historical contexts are means of reproducing or contesting the existing relationships to serve different interests. How is the text positioned or positioning? Whose interests are served by this positioning? Whose interests are negated? What are the consequences of this positioning? Where analysis seeks to understand how discourse is implicated in relations of power, it is called Critical Discourse Analysis.

In 1960s and 1970s several scholars adopted a more critical perspective in language studies. A French scholar Pecheux (1992) introduced integration of language and social process. He was greatly influenced by the work of Russian scholars Bakhtin and Volosinov, who had used the integration of language and social process in the 1930s.

In late 1970s, a group of Hallidayan linguists at the University of East Angelia started to apply the term 'critical linguistics' (CL) in their research on language used in different institutions (Fowler et al., 1979; Kress \& Hodges 1979). Their approach was based on Halliday's systematic Functional Linguistics (SFL). Language, according to CL practitioners, performs three functions: ideational, interpersonal, and textual. To Fowler (et al. 1991) and Fairclough (1995) the ideational function refers to the experience of the speakers of the world and its phenomena, the interpersonal function embodies insertion of speakers' own attitudes and evaluations about phenomena in question. This is the third function, textual function that speakers are able to produce the texts that are understood by listeners. It is an enabling functions connecting discourse.

Over the years CL and what recently is frequently referred as CDA (Choulariaki \& Fairclough 1999; Van Djik 1998) has been further developed and broadened the main concerns regarding CL were consideration about the role of audiences and their interpretations of discourse possibly different from that of discourse of analyst and secondly, emphasize on the scope of analysis beyond inter-textual analysis. According to body Barret (1994) finds that there is a tendency towards the classic fallacy of attributing particular readings to readers, or media 'effects' solely on the basis of textual analysis. Fairclough (1995) has questioned both issues. He claims that earliest work in CL did not sufficiently focus on the "interpretative practice of audiences" and seems supporting to Body-Barret.

Despite raising these issues with regards to earlier works in CL, Fairclough (1995) inserts that "mention of these limitations is not meant to minimize the achievement of critical linguistics...they largely reflect shift of focus and developments of theory in the past twenty two years or so." This shift of focus and developments of theory have not resulted in the creation of a simple theoretical framework. Presently what is called CDA" is best varied as a shared perspective encompassing a range of approaches rather than just one school" (Bell \& Garret 1998).CDA "is not a specific directions of research" hence "it does not have a unitary theoretical framework" (Van Djik 1998).

\section{CDA Models}

Van Djik's Socio-Cognitive Model(1988,1991,1993,1995,1998b,1998a), Wodak's Discourse SocioLinguistics $(1995,1996,1999)$, Theo Van Leeuwen's Socio Semiotics (1993) and Norman Fairclough's Critical Discourse Analysis(1989,1993,1995a,1995b,1999) have immensely contributed to the development of CDA and its trends. At this point of literature review pertaining to CDA, it seems appropriate to briefly look into all CDA models mentioned above.

\section{VanDjik (Socio-Cognitive Model)}

Van Djik commenced to apply his discourse analysis theory to media exclusively focusing on the representation of ethnic groups and minorities in Europe. In his News Analysis (1998), he unifies his general theory to authentic network cases of news reports at both national and international level. The distinguished features of Van Djik (1988) framework for the analysis of news discourse is a thorough analysis not only of textual and structural level of media discourse but also for analysis and explanation, production and reception or comprehensive level (Body-Barret, 1994).

By structural analysis, Van Djik posited analysis of "structures at various levels of description" News Analysis is that meant not only the grammatical, phonological, morphological and semantic level but also 'higher level properties' such as coherence, overall themes and topics of news stories and whole schematic forces and rhetorical dimensions of texts. In Socio-Linguistics Model "production processes" means journalistic and institutional practices of news forcing the economic and social practices those not only play significant role but also explicitly related to the structures of discourse. Another feature of Van Djik's News Analysis is "Reception Processes" that involves the comprehension, memorization, and reproduction of news information. 
At micro-structure level, analysis is focused on semantic relations between propositions, syntactic, lexical and other rhetorical elements that provide coherence in texts. The focal point in Socio-Cognitive CDA Model of Van Djik , however, is the analysis of macro-structure. Since this is related to the thematic structure of news analysis.

For Van Djik (1988), the news schemata (Superstructure Schema) are structured according to a specific narrative pattern that consists of summary, (Headlines) story (Episode and background) and consequences (Final situation and comments). Van Djik (1995) considers discourse as ideology analysis. To him, ideologies are typically, though not specifically, expressed and reproduced in discourse and communication, including Semiotic messages such as pictures, photographs, movies and signs. To him social cognition mediates between society and discourse. He believes that one who wants to make transparent such as ideological dichotomy in discourse needs to analyze discourse:

a- Examining the context of discourse; historical, political, or social background of a conflict and its main participants.

b- Analyzing power relations and conflicts involved.

c- Identifying positive and negative opinions US versus Them.

d- Making explicit the presupposed and implied.

e- Evaluating all formal structures.

Van Dajik is significant representative of this approach, most his critical work focuses on the reproduction of ethnic prejudices and racism in discourse and communication. His approach is very researchers who are interested in ethnographic research and related social issues in higher education.

\section{Wodak (Discourse Socio- Linguistic)}

Ruth Wodak and her group of researchers in Vienna constructed their model of CDA on sociolinguistics in Berstenian tradition, and on the ideas of the Frankfurt school, specifically those of Habermas.

Wodak (1996) explains that discourse Sociolinguistics is ...a sociolinguistics which not only is explicitly dedicated to the study of the text in context, but also accords both factors equally important. It is an approach capable of identifying and describing the underlying mechanism that contribute to those disorders in discourse which are embedded in a particular context - if they be in the structure and function of the media, or institutions such as hospitals, or school and inevitably affect communication. She actually conducted her research on institutional communication and speech barriers in court, in schools, and hospital clinic and recently she has concentrated on sexism and contemporary anti-Semitism and racism in settings of various degrees of formality. In an interdisciplinary study of post war anti-Semitism in Australia completed in 1990, Wodak and her colleagues developed a research method termed as discourse historical approach/method. The distinctive feature of this approach is its attempt to integrate systematically all available background information in the analysis and interpretation of many layers of a written or spoken text. Wodak et al. (1990) were able to show the context of the discourse had a significant impact on the structure, function, anti-Semitic utterances. Language "manifests social processes and interaction" and "constitutes" those processes as well is focal point to the discourse of historical approach (Wodak \& Ludwig, 1999).

Discourse Historical Approach or method can be used to enable the analysis of indirect prejudiced utterances, as well as to identify and expose the codes and allusions contained in prejudiced discourse.

\section{Kress and Leeuwen (Social Semiotics Model)}

In early 1970s, Halliday stressed the relationship between the grammatical systems and the personal as well as personal needs that language is to serve. Halliday distinguished three connected meta-function of language, (a) the ideational, (b)inter-personal (c) the textual function. Gunther Kress (1970) was greatly influenced by Hallidayan School of thought. His works served as an example of the tradition which labeled itself CL from the beginning. He has developed his Model and methodology since his early work in 1979. Kress is concerned with the central notion of "the sign as an indissoluble conjunct of meaning and form". In his own word, he would like "to connect the specifications of Semiotics forms in any medium, with specifications of social organization and social histories.(Kress 1993). Kress concentrated on 'political economy' of representational media: that is an effort to find how various societies value different modes of representations. His work has displayed a growing interest in the description, analysis, and theorizing of other Semiotic media, in particular visual media (Kress \& Leeuwen 1990).

Other prominent representative of Social Semiotic Model Theo Van Leeuwen focuses specifically on fiction and Semiotics (film, caricatures, pictures, signs etc). Leeuwen (1993) distinguishes two kinds of relationships between discourses and social practices, "discourses itself as social practices, discourses as form of actions as something people do to or for with each other. And there is discourse in the foucauldian sense; discourse is a way of representing social practices as a form of knowledge, as the thing people say about social 
practices. Leeuwen (1993) defines that CDA should be concerned with discourse as the instrument power and control as well as discourse as the instrument of the social construction of reality.

\section{Fairclough CDA Model}

During past ten years, the Fairclough approach in CDA has attained the status of nucleus in CDA. In his earlier work Fairclough, called his earlier approach to language and discourse critical language study (1989,p.5).he described of aim of this approach as " a contribution to the general raising of consciousness of exploitative social relations through focusing upon language"(Fairclough,1989).

In his works $(1985,1989,1993)$, Fairclough sees the importance of CDA as a method to use alongside others in research on social and cultural change, and as a resource in struggles against exploitation and domination. He is mainly concerned with the study of power and institutional discourse, stressing the intertextuality of different forces of social practices.

Fairclough $(1989,1995)$ model for CDA consists three inter related processes of analysis tied to three inter related dimensions of discourse;

a- The object of analysis(verbal, visual or verbal, and visual texts),

b- The processes by means of which the object is produced and received (writing/speaking/designing and reading/ listening/viewing)by human subjects

c- The socio-historical conditions which governs these processes.

He emphasizes that each of these discourse needs a different kind of analysis. He suggests:

a- Text analysis (description)

b- Processing analysis(interpretation)

c- Social analysis (explanation).

Chouliaraki \& Faiclough (1999) find that CDA of a communicative interaction sets out to show that the semiotic and linguistic features of the interaction are systematically connected with what is going on socially, and what is going on socially is indeed going on partly or completely semiotically or linguistically.

This approach is beneficial to use as research methodology not only in the field of linguistics, Semiotics but also in Social Sciences at higher education level. It enables a research to focus on the signifiers that make up text, the specific signified linguistics selections, their juxtapositioning, their sequencing, and their layout and so on.

\section{Principles of CDA}

The principles of CDA outlined by the practitioners (Kress, 1991; Hodges \& Kress, 1993; Fairclough, 1995; Van Djik, 1998; wodak, 1996) can be summarized as follows:

a- Language is a social practice through which the world is represented.

b- Discourse use a form of social practice in itself and signifies other social practices such exercise of power, domination, prejudice, resistance etc.

c- Texts acquire their meanings by dialectical relationship between text and social subjects, writers and readers.

d- Linguistic features and structures are not arbitrary.

e- Power relations are produced, exercised, and reproduced through discourse.

f- Discourse is historical in the sense that texts attain their meanings by existing in specific social. Cultural and ideological contexts, time and space.

g- CDA not only interprets texts abut explains them also.

h- All speakers and writers work in specific discursive practices stemming from special interests and aims.

\section{The critical use of Critical Discourse Analysis (CDA)}

The critical use of discourse analysis (CDA) apply in linguistics is leading to the development of a different approach to understanding media messages. Robert Kaplan (1990) expressed some of these new concepts when he wrote: "The text, whether written or oral, is a multidimensional structure," and "any text is layered, like a sheet of thick plywood consisting of many thin sheets lying at different angles to each other." The basics of a text consist of syntax and lexicon; its grammar, morphology, phonology, and semantics. However, "The understanding... of grammar and lexicon does not constitute the understanding...of text." "Rhetoric intent...," says Kaplan, "coherence and the world view that author and receptor bring to the text are essential."

\section{What is Critical in CDA?}

The term 'critical' in CDA is often associated with studying power relations. The concept of critical is rooted in the Frankfurt School of Critical theory (Adorno,1973; Adorno \& Horkeimer,1992, Habermas,1976). Critical research and theory is the rejection of naturalism, (that social practices, labels, programs represents reality), rationality(the assumptions that truth is a result of science and logic), neutrality (the assumption that 
truth does not reflect any particular interest), and individualism. Roger, (2003). She maintains that critical research rejects the over deterministic view of social theory espoused by the Marxists and instead argues for dialectic between individual agency and structural determinism. Therefore the critical discourse analysis is a dialectical. Another interpretation of 'critical' is that CDA especially addressed social problems and seeks to solve social problems through the analysis and accompanying social and political action (Roger, 2003).

\section{Difference between Traditional Discourse Analysis and CDA}

Critical discourse analysis differs from traditional Discourse Analysis in the sense that it implies adopting a critical perspective ( Vaara \& Tienari 2004). CDA may be generally seen as a branch of critical scholarship ( Leitch \& Palmer 2010), and as a methodology it allows us to examine the role discourses have in constituting the world we live in. Due to this constructive nature discourses, in fact, (re-)produce knowledge, culture, identities, subjectivities, and power relationships in social and societal settings ( Vaara \& Tienari, 2004, p. 344). Therefore, discourses can be regarded as an important element of social practices, which are not, however, reducible to discourse, but rather articulations of discourse that contain also non-discursive elements (Fairclough, 2005).

CDA researchers study discourse by placing texts in their context, rather than as isolated objects. Context in this sense is an analytical construct that emerges from specific research questions and seeks to define - in addition to being defined by - the articulation of moments that is relevant to the constitution of specific kinds of organizational texts (Chouliaraki \& Fairclough2010). Context itself is best conceptualized as an epistemic object dialectically arising out of the multitude of ways by which CDA problematizes discourse as an instrument of power (Chouliaraki \& Fairclough, 2010).

Vaara \& Tienari (2004) point out that this kind of context-related research demands the ability to make sense of both the links between specific textual characteristics and related discourses as well as the links between the discourses and the corresponding socio-cultural practices. Therefore, CDA research tends to favor in-depth analysis of and holistic learning from specific texts rather than quantitative measures, such as content analysis (Vaara \& Tienari 2004).

The concern of CDA research is with the relationship and tensions between pre-constructed social structures, practices, identities, orders of discourse and organizations on the one hand, and processes, actions, events on the other ( Fairclough , 2005, p. 923). Critical discourse analysis is, thus, united by its critical lens, which is focused on the ways in which knowledge, subjects, and power relations are produced, reproduced, and transformed within discourse, and is operationalized through a variety of methods to analyze texts in context ( Leitch \& Palmer, 2010).

\section{Research in Higher Education}

\section{CDA as Research Methodology}

Huckin et al.(2012) claim we posit CDA as a promising methodology for the study of many traditional objects of writing studies(e.g., multimedia texts, composing practices, teaching practices) and rhetorical criticism(e.g., diction, style, genre, argument, critical thinking).

CDA principles and concepts have also proved significant in examining ways in which power is constructed rhetorically in educational spheres. Fairclough (1995) explains extensively about the commodification of higher education in Britain and more recently CDA scholars in North America have taken up the topics as well. Educational policy researcher Eric Haas and education scholar Gustavo Fischman created a large corpus of texts on higher education to analyze the decision making processes in higher education management. They combined CDA with Eleanor's, Rosch's and George Lakoff's theories to reveal three predominant kinds of educational discourse prototype (Huckin et al., 2012). David Ayes renowned educational scholar adopts a more local view to analyzing 178 texts published on budget websites at three state universities in USA (Huckin et al., 2012).

\section{CDA and Critical Pedagogy}

CDA offers a an effective research methodology for carrying out research not only in the area of the discourse of educational institutions discourse but also that of the classroom itself, making it useful to scholars and practitioners of critical pedagogy. One prime tenet of critical pedagogy is that classroom is a place in which power is circulated, managed, exploited, resisted and often directly impacted by institutional policies and changes (Huckin et al., 2012).

CDA can complement and extend existing critical and radical writing pedagogies. This research methodology can also be applied in assessing the pedagogies efficacy. For instance, linguist Patracia Mayes analyzed power relations into two sections of a US composition course that were following a critical pedagogy curriculum (Huckin et al., 2012). 


\section{CDA and Media}

CDA is a suitable research tool in the field of media and communication with its attention to both textual detail and socio-political context. CDA is exclusively well quoted to help instructors and students conduct insight critiques how events are depicted in media? Thomas Huckin has used a a corpus of 163 news articles to analyze an editorial and feature story about homeless, showing how contrasting patterns of what he calls 'textual silences' promoted ideological frames (Huckin et al. 2012).

\section{Research Methodology}

Historical research is a systematic process of searching for the facts and then using the information to desirable, analyze, and interpret the past (Weirsma and Jurs, 2009). Historical research may have a variety of foci. It helps to focus on issues, movements, and concepts in education. As the researcher use the documents, interpretation again takes place. Context and interpretation are essential elements of historical research. Therefore, history requires the importance of understanding the full context of events- the deeper causes and the long range consequence (Ellenwood, 2007). The primary sources were used to benefit for this paper. The study was based on the question; can CDA be used as method/approach in educational research?

\section{Objective of the study}

The study aimed to have a review of research - based literature related to CDA and educational research. It also aims to suggest the use of CDA in educational research.

\section{Findings}

CDA has become an established academic discipline with the same rituals and institutional practices as all other academic discipline. The interest in CDA as research tool is developing swiftly, and the critical perspective is emerging essentially as a research methodology for the investigation of language use. CDA is developing into interdisciplinary research domain par excellence, and thus offer interesting perspective for integrated research on language in society. MaCgee and Fraser (2000), defines that professional practices refer to the ideas and practices that mark the (teachers) researchers out as professional decision makers. These researchers inform their practice by a critical consideration of theory and knowledge. CDA helps researchers (teachers) to investigate the relations between the ideas and the practices in the social contexts. We posit CDA as a promising methodology for the study of many traditional objects of writings studies (e.g., multimodal texts, composing practices, teaching practices), and rhetorical criticism (e.g., diction, style, genre, argument, critical thinking) (Huckin et al., 2012).

CDA aligns itself with the tradition in attending to purpose, situation, genre, diction, style, and other rhetorical variables but also supplements it in number of ways:

a- CDA grounds its analysis in both quantitative and qualitative attention to linguistic details.

b- It routinely engages texts that reflect inequality or other abuses of power.

c- It is always critical and explanatory.

d- It is eclectic, drawing a variety of scholarly disciplines, concepts, and research methods.

e- It takes into accounts 'textual silence', ambiguities and other covert but powerful discourses.

f- It tries to minimize the use of academic jargon and makes use of multiple texts.

However, CDA is often critiqued around the following dimensions:

a- Political and Social ideologies are projected onto the data rather than being reveled through the data.

b- There is an unequal balance between social theory and linguistic method.

c- Many discourse analyses are extracted from social contexts.

d- This methodology is not systematic (Roger, et al., 2003; Widdowson, 1998).

\section{Conclusion}

CDA is multidisciplinary approach that is being widely applied to explore the link between the educational practices and social contexts. Educational researchers are interested in how text are put together (Bloom \& Certer, 2001; Lemke, 1992; Peyntong-Young, 2001), studies of policy (Collins, 2001; Corson,2000, Woodside-Jiron,2000), and interactions in classrooms and schools ( Bloome \& Egan-Robertson, 1993; Kumarvadivelu,1999; Roger,2003). All of these studies are linked in their inquiry into the relationship between language and social configuration of education. According to Bukhari et al., (2012) there are changes in teaching, learning and curriculum, and school and community role has also changed that laid impacts upon teachers' roles. It is likely that teachers should understand the relationship of educational research and teachinglearning process. The existing theories, approaches to curriculum as well as teaching strategies essentially help the teachers to innovate their professional practice of teaching. In order to execute their professional practices, teachers need to acquire ample knowledge and many skills. Not so long ago teaching was considered as an 
emerging applied science based upon laws of cause and effect. A skilled teacher can orchestrate the complex activities of classroom. Professionals are also need to be lifelong learner.

In the view of this perspective CDA is useful to investigate the relationships between the teaching, learning and curriculum, and school and community role as well as ideologies and power (basic factor for educational policies) and their impacts on the classroom process and teaching - learning activity. The CDA can effectively be applied for exploring the educational issues in the contexts of conflict between power and social realities.CDA is an emerging method of research despite the fact that it still needs to be improved and established as an authentic method.

\section{References}

[1]. Adorno,T. (1973). Negative Dialectics. New York: Seabuy.

[2]. Adorno,T \& Horkeimer,M. (1972). Dialectic of Enlightenment. New York Herder \& Herder.

[3]. Bernstein B. (1990). The Structuring of Pedagogic Discourse, London: Routledge.

[4]. Bloom,D (1999). Book review of critical discourse of Analysis. Reading Research Quarterly.

[5]. Boyd-Barrett, Oliver (1994) Language and media: a question of convergence. In David Graddol \& Oliver Boyd-Barrett (eds.). Media Texts: Authors and Readers. Clevendon: Multilingual Matters Ltd. (pp.22-39)

[6]. Bukhari et al., (2012) Dimension of Research in Teaching: A Critical Review. Elixir Edu.Tech. (50) (2012) 10289-10293. Available online at elixir.journal.org

[7]. Chouliaraki L., and Fairclough, N. (1999) Discourse in Late Modernity. Edinburgh.

[8]. Corson,D. (2000) Emancipatory Leadership. International Journal of Leadership in Education, 3(2),93-120

[9]. Lemke. J. (1992) Intertextuality and Educational Research. Linguistic and Education, 4, 257-267

[10]. Ellenwood, S. (2006) Receiving character education : From McGuffy to Narratives.

[11]. Fairclough, N. (1989) Language and Power. London: Longman.

[12]. Fairclough, N. (1992). Discourse and Social Change. Cambridge: Polity Press.

[13]. Fairclough, N. (1995) Critical Discourse Analysis. London: Longman.

[14]. Fairclough, N. (1995a). Critical Discourse Analysis: The Critical Study of Language. London: Longman.

[15]. Fairclough, N.(1995b). Media Discourse. London: Edward Arnold.

[16]. Fariclough, Norman (1996). A reply to Henry Widdowson's "Discourse analysis: a critical view". Language and Literature, 1996, 5 (1): 49-56 Fowler, R. and Hodge.B. (1979). Critical linguistics. In R. Fowler et al (Eds.). (Eds.). Language and Control. London: Routledge and KeeganPaul. pp. 185-213

[17]. Garrett (Eds.). Approaches to Media Discourse. Oxford: Blackwell.

[18]. Gee, J.P. (1999) An Introduction to Discourse Analysis. London: Routledge.

[19]. Gramsci A., 1971, Selections from the Prison Notebooks, Lawrence \& Wishart, London.

[20]. Habermas, J. (1976) Ligitimation Crisis. London : Heineam Educational Books.

[21]. Janks, H. (1997) Critical Discourse Analysis as a Research Tool. Discourse: Studies in the cultural politics of education, 18(3): 32942.

[22]. Jokinen, A., Juhila, K. \& Suoninen, E. (1993), Diskurssianalyysin aakkoset. Tampere: Vastapaino.

[23]. Kress, G. and van Leeuwen, T. (1990) Reading Images. (Victoria, Deakin University Press).

[24]. Halliday, M.A.K. (1994). Introduction to Functional Grammar. London: Edward Arnold.

[25]. Harvey D., 1996, Justice, Nature and the Geography of Difference, Blackwell, Oxford.

[26]. Hodge, R. and Kress, G. (1993). Language as Ideology. $2^{\text {nd }}$ Ed. London: Routledge

[27]. Huckin et al., (2012) Critical Discourse analysis and Rhetoric and Composition. Available on www.ncte.org

[28]. Kaplan, R. (1990),"Concluding Essay: On Applied Linguistics and Discourse Kress, G. (1990). Critical discourse analysis. Annual Review of Applied Language \& Communication, vol.17, No.3:237-248

[29]. Krings.H. et al (1993). Handbuch philosophicher Grundbegriffe. Kosel.

[30]. Leeuwen.T.V. (2005). Introducing Social Semiotics. London: Routledge.

[31]. Leitch, S. \& Palmer, I. (2010), Analysing Texts in Context: Current Practices and New Protocols for Critical Discourse Analysis in Organization Studies, Journal of Management Studies, 47(6), 1194-1212.

[32]. McGee, \& Fraser, D. (2005). The Professional Practice of Teaching. Auckland Thomson Dunmore Press.

[33]. Rogers.R (2004). Introduction to Critical Discourse Analysis in Education. London: Lawrence Erlbaum Associates, Publishers.

[34]. Threadgold, T. and B. Kamler (1997). "An interview with Terry Threadgold on critical discourse Analysis." Discourse: Studies in the Cultural Politics of Education 18: 437-451.

[35]. Van Dijk, T.A. (1998a). Critical discourse analysis. Availabale at http://www.hum.uva.nl/teun/cda.htm. (1/25/2000).

[36]. Van Dijk, T.A. (1998b). Opinions and Ideologies in the Press. In Bell, Allan and Peter Verschuren, Jan-Ola Ostman, and Jan Blommaert (eds). Handbook of Pragmatics- welfare reform, Journal of Sociolinguistics 4, pp. 163-195

[37]. Van Dijk, T.A. (1993). Elite Discourse and Racism. London: Sage Publications. Pp.242-282

[38]. Van Dijk, T.A. (1991). Racism and the Press. London: Routledge.

[39]. Van Dijk, T.A. (1988a). News Analysis: Case Studies of International and National News in the Press. Hillsdale, N.J.: Lawrence Erlbaum Associates. Van Dijk (1988b). News as Discourse. Hillside, NJ: Erlbaum.

[40]. Vaara, E. \& Tienari, J. (2004), Critical Discourse Analysis as a Methodology for International Business Studies, in Handbook of Qualitative Research Methods for International Business, Eds. Rebecca Piekkari and Catherine Welch.Cheltenham, Northampton, MA: Edward Elgar,pp. 342-359.

[41]. Volosinov, V.N. (1973) Marxism and the Philosophy of Language. Tr. Matejka,L. andTitunik, I.R. New York: Seminar Press.

[42]. Widdowson, H. G. (1995). Discourse analysis: a critical view. Language and Literature 4 (3): 157-72

[43]. Widdowson, H.G. (1998) The Theory and Practice of Critical Discourse Analysis. Applied Linguistics, 19/1: 136-151 Williams.G. (1992). Sociolinguistics. London: Routledge.

[44]. Williams.R. (19770. Marxism and Literature. London: Oxford University Press. Wodak, R. \& Ludwig, Ch. (Ed.) (1999). Challenges in a changing world: Issues in Critical Discourse Analysis, Vienna: Passagenverlag.

[45]. Wodak, R. (1996). Orders of Discourse. New York: Addison Wesley Longman.pp.(1-21)

[46]. Wodak, R. (1995). Critical Linguistics and Critical Discourse Analysis. In Jef Verschuren, Jan-Ola Ostman, and Jan Blommaert (eds.).Handbook of Pragmatics- Manual. Amsterdam/Philadelphia: John Benjamins Publishing Company. Pp. 204-210.

[47]. Wodak, R. (1996). Orders of Discourse. New York: Addison Wesley Longman. 
[48]. Wodak, R. (2000a). Discourses of Exclusion: a European Comparative Study: Speech at the Opening of the EU Observatorium, 7/8 April, 2000, Hofburg Vienna. www.tuwien.ac.at/diskurs/stellungnahmen/Wodak5.html (February 10, 2001).

[49]. Weirsma, William \& Jurs, S.G. (2009). Research Methods in Education: An Introduction. New Delhi: Pearson. 